\title{
Residual Disease after Operative Hysteroscopy in Patients with Endometrioid Endometrial Cancer Associated with Polyps
}

\section{Doença residual após histeroscopia cirúrgica em pacientes com câncer de endométrio endometrioide associado a pólipo endometrial}

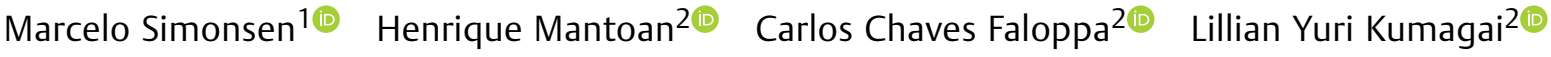

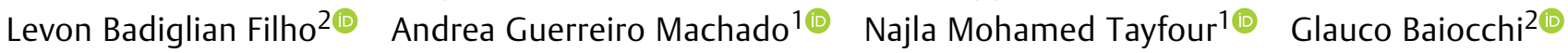 \\ ${ }^{1}$ Department of Gynecologic Oncology, Instituto de Assistência Médica ao \\ Servidor Público Estadual de São Paulo, São Paulo, SP, Brazil \\ Address for correspondence Marcelo Simonsen, Rua Pedro de Toledo, \\ 2 Department of Gynecologic Oncology, Hospital AC Camargo, \\ 1800, Vila Clementino, São Paulo, SP, 04039-000, Brazil \\ São Paulo, SP, Brazil \\ (e-mail: drmarcelosimonsen@gmail.com).
}

Rev Bras Ginecol Obstet 2021;43(1):35-40.

\begin{abstract}
Keywords

- endometrial neoplasm

- hysteroscopy

- endometrial polyp

Objective To evaluate the presence of residual disease in the uterine specimen after hysteroscopic polypectomy or polyp biopsy in patients with endometrioid endometrial cancer (EC).

Methods We analyzed a series of 104 patients (92 cases from the Hospital AC Camargo and 12 from the Hospital do Servidor Público Estadual de São Paulo) with polyps that were diagnosed by hysteroscopy, showing endometrioid EC associated with the polyp or in the final pathological specimen. Patients underwent a surgical approach for endometrial cancer from January 2002 to January 2017. Their clinical and pathological data were retrospectively retrieved from the medical records.

Results In 78 cases (75\%), the polyp had EC, and in 40 (38.5\%), it was restricted to the polyp, without endometrial involvement. The pathologic stage was IA in 96 cases $(92.3 \%$ ) and 90 (86.5\%) had histologic grade 1 or 2 . In 18 cases (17.3\%), there was no residual disease in the final uterine specimen, but only in 9 of them the hysteroscopy suggested that the tumor was restricted to the polyp. In 5 cases (4.8\%) from the group without outside of the polyp during hysteroscopy, myometrial invasion was noted in the final uterine specimen. This finding suggests the possibility of disease extrapolation through the base of the polyp.

Conclusion Patients with endometrioid EC associated with polyps may have the tumor completely removed during hysteroscopy, but the variables shown in the present study could not safely predict which patient would have no residual disease.
\end{abstract}

received

February 26, 2020

accepted

September 14, 2020
DOI https://doi.org/

10.1055/s-0040-1719145. ISSN $0100-7203$. (c) 2021. Federação Brasileira das Associações de Ginecologia e Obstetrícia. All rights reserved.

This is an open access article published by Thieme under the terms of the Creative Commons Attribution License, permitting unrestricted use, distribution, and reproduction so long as the original work is properly cited. (https://creativecommons.org/licenses/by/4.0/)

Thieme Revinter Publicações Ltda., Rua do Matoso 170, Rio de Janeiro, RJ, CEP 20270-135, Brazil 


\section{Resumo}
Palavras-chave
- câncer de endométrio
- histeroscopia
- pólipo endometrial

Objetivo Avaliar a presença de doença residual no exame anatomopatológico definitivo de pacientes com câncer de endométrio endometrioide após polipectomia ou biópsia de pólipo histeroscópica.

Métodos Analisamos 104 pacientes (92 casos do Hospital AC Camargo e 12 casos do Hospital do Servidor Público Estadual de São Paulo) com pólipos diagnosticados durante histeroscopia e cuja biópsia histeroscópica ou exame patológico final do útero acusaram câncer de endométrio endometrioide. As pacientes foram submetidas a cirurgia para câncer de endométrio de janeiro de 2002 a janeiro de 2017. Os dados clínicos e anatomopatológicos de cada paciente foram retirados dos prontuários médicos

Resultados Em 78 casos (75\%), o pólipo continha a neoplasia, e em 40 (38.5\%), ela estava restrita ao tecido do pólipo, sem envolvimento endometrial adjacente. O estadio final foi IA em 96 casos (92.3\%) e em 90 (86.5\%) tratava-se de grau 1 ou 2. Em 18 casos (17.3\%), não havia doença residual no espécime uterino, mas em apenas 9 deles a histeroscopia sugeriu doença restrita ao pólipo. Em 5 casos (4.8\%), não havia doença aparente extrapólipo na histeroscopia, mas havia invasão miometrial, sugerindo extravasamento do tumor pela base do pólipo.

Conclusão Pacientes com câncer de endométrio associado a pólipos podem ter o tumor completamente removido durante a histeroscopia, mas, com as variáveis avaliadas, é difícil predizer com segurança qual paciente ficará sem tumor residual.

\section{Introduction}

Patients with endometrial cancer (EC) present with polyps at the time of diagnosis between 10 and $30 \%$ of the cases. ${ }^{1,2}$ If the tumor originates from a typical polyp, it is described as a neoplastic polyp, but if the cancer acquires a polypoid configuration, it is classified as a polypoid cancer. ${ }^{2}$ Patients with concomitant endometrial polyps and cancer usually present in earlier stages than those with tumors that are not associated with a polyp. ${ }^{1}$

Molecularly, the epithelium of the polyp differs from that of the endometrium, ${ }^{3,4}$ but can be as prone to carcinogenesis as the normal endometrium. ${ }^{1}$ Although the risk factors for endometrial neoplasms are the same for polyps and normal endometrium, ${ }^{1,5}$ the histological findings of the polyp might not reflect the condition of the adjacent endometrium. ${ }^{5}$

Few studies have described the aggressiveness of a tumor that is associated with polyps. ${ }^{1,6}$ In the case of EC in a polyp, the thickness of the parenchyma of the polyp can be a protective factor against myometrial invasion, based on reports of the absence of residual disease after polypectomy in patients with EC. ${ }^{1,2}$

Atypical hyperplasia in a polyp usually requires a more conservative treatment. ${ }^{7,8}$ Even histologically high-grade cancer that originates in a polyp can present as confined uterine disease $^{9}$ and thus receive less adjuvant treatment. ${ }^{10}$ Moreover, endometrioid tumors appear to be less aggressive when they are restricted to a polyp, ${ }^{11}$ but studies that have characterized such tumors are lacking.
Our aim was to correlate the location of endometrioid EC (within the polyp and/or the adjacent endometrium) with clinical and pathological factors, trying to find a subgroup of patients prone to the absence of residual neoplasia in the final uterine specimen.

\section{Methods}

We analyzed a sequential series of 104 patients (92 cases from the Hospital AC Camargo and 12 from the Hospital do Servidor Público Estadual de São Paulo) who had presented endometrial polyps in the hysteroscopy and undergone surgery for EC from January 2002 to January 2017. Clinical and pathological data were retrospectively retrieved from their medical records. The respective institutional ethical review boards approved the present study (approval CAAE numbers 70580117.9.1001.5463/ 70580117.9.2001.5432).

We included patients with polyps and a diagnosis of EC. The diagnosis was achieved by hysteroscopic biopsy/polypectomy or defined after hysterectomy, based on the definitive pathologic uterine specimen. Patients with nonendometrioid tumors were excluded. Staging and grade were defined according to the International Federation of Gynecology and Obstetrics (FIGO) classification. ${ }^{12}$

A database was constructed using SPSS for Mac, version 20.0 (SPSS, Inc., Chicago, IL, USA). The chi-squared and Fisher exact tests were used to analyze the correlations between categories and clinicopathological variables. For all tests, an $\alpha$ error of up to $5 \%(p<0.05)$ was considered significant. 
Table 1 Clinical and pathological variables of the 104 patients with a diagnosis of endometrial polyps and cancer

\begin{tabular}{lll}
\hline Clinical variables & $\mathbf{n}=\mathbf{1 0 4}$ & \% \\
\hline Age - years old (mean) & 58 & \\
Menopause & 87 & 83.7 \\
Bleeding & 61 & 58.1 \\
Lymph node dissection & 75 & 72.1 \\
Absence of residual tumor & 18 & 17.3 \\
\hline
\end{tabular}

\section{Results}

The clinical and pathological characteristics are summarized in - Table 1. Menopause was described in 87 patients (83.7\%), and the main symptom was vaginal bleeding. A high percentage of patients had lymph node dissection (72\%), but no cases of lymph node involvement were observed.

- Table 2 lists the pathological variables according to the location of the tumor. In 78 cases (75\%), the EC involved the polyp and the adjacent endometrium and in 40 (38.5\%), it was restricted to the polyp, with no endometrial involve- ment. Moreover, in 16 cases (15.3\%), the EC involved only the adjacent endometrium. In 10 (9.6\%) cases, the polyp biopsy showed atypical hyperplasia and EC was detected only in the final pathological specimen. There was no correlation between the presence of postmenopausal bleeding and the exact location of the EC $(p=0.42)$.

Most cases ( $n=96 ; 92.3 \%$ ) were classified as stage IA and $90(86.5 \%)$ were classified as grade 1 or 2 . In 18 cases (17.3\%), there was no residual tumor in the definitive hysterectomy specimen (-Table 3); however, of the 40 cases in which the tumor was apparently restricted to the polyp, 5 (12.5\%) showed deep myometrial invasion in the definitive uterine specimen.

Cancer that was localized in the polyp by hysteroscopy was unrelated to a higher percentage of final specimens without disease ( - Table 3). Even when cases with tumor involvement outside of the polyp were grouped, there was no significant impact on the presence of residual disease $(p=0.20)$. Moreover, there was no significant association between polyp-restricted tumors and early-stage disease $(p=0.13)$. Grade 3 tumors occurred irrespective of the precise location of the neoplasm. Of the 14 high-grade tumors (13.4\%), 3 were IB tumors (-Table 3 ). Complete removal (with no residual disease) of the 14 grade 3 tumors by hysteroscopy was achieved in 5 patients (35.6\%) and in 13 of the 90 grade 1 or 2 tumors $(14.4 \%)(p=0.064)$.

Table 2 Symptoms and hysteroscopic findings of the 104 patients with a diagnosis of endometrial polyps and cancer

\begin{tabular}{|c|c|c|c|c|c|c|}
\hline Data & Status & $\begin{array}{l}\text { Polyp } \\
\text { involvement } \\
(n=40)\end{array}$ & $\begin{array}{l}\text { Polyp and endometrial } \\
\text { involvement }(n=38)\end{array}$ & $\begin{array}{l}\text { Endometrial } \\
\text { involvement } \\
(n=16)\end{array}$ & $\begin{array}{l}\text { Neoplasm only in } \\
\text { final specimen (10) }\end{array}$ & p-value \\
\hline Bleeding & $\begin{array}{l}\text { Yes } \\
\text { No }\end{array}$ & $\begin{array}{l}24 \\
16\end{array}$ & $\begin{array}{l}25 \\
13\end{array}$ & $\begin{array}{l}8 \\
8\end{array}$ & $\begin{array}{l}4 \\
6\end{array}$ & 0.42 \\
\hline Number of polyps & $\begin{array}{l}1 \\
2 \\
3+ \\
\text { Not described }\end{array}$ & $\begin{array}{l}17 \\
6 \\
4 \\
13\end{array}$ & $\begin{array}{l}16 \\
2 \\
6 \\
14\end{array}$ & $\begin{array}{l}8 \\
0 \\
0 \\
8\end{array}$ & $\begin{array}{l}3 \\
3 \\
0 \\
4\end{array}$ & 0.25 \\
\hline Polyp procedure & $\begin{array}{l}\text { Excision } \\
\text { Biopsy } \\
\text { not described }\end{array}$ & $\begin{array}{l}18 \\
3 \\
19\end{array}$ & $\begin{array}{l}28 \\
4 \\
6\end{array}$ & $\begin{array}{l}7 \\
1 \\
8\end{array}$ & $\begin{array}{l}4 \\
2 \\
4\end{array}$ & 0.59 \\
\hline
\end{tabular}

Table 3 Final pathological report variables of the 104 patients with a diagnosis of endometrial polyps and cancer

\begin{tabular}{|c|c|c|c|c|c|c|c|}
\hline Data & Status & $\begin{array}{l}\text { Polyp } \\
\text { involvement } \\
(n=40)\end{array}$ & $\begin{array}{l}\text { Polyp and endometrial } \\
\text { involvement }(n=38)\end{array}$ & $\begin{array}{l}\text { Endometrial } \\
\text { involvement } \\
(n=16)\end{array}$ & $\begin{array}{l}\text { Neoplasm only in } \\
\text { final specimen }(n=10)\end{array}$ & Total & p-value \\
\hline Residual tumor & $\begin{array}{l}\text { Absent } \\
\text { Present }\end{array}$ & $\begin{array}{l}9 \\
31\end{array}$ & $\begin{array}{l}6 \\
32\end{array}$ & $\begin{array}{l}3 \\
13\end{array}$ & $\begin{array}{l}0 \\
10\end{array}$ & $\begin{array}{l}18 \\
86\end{array}$ & 0.45 \\
\hline Stage & $\begin{array}{l}\mathrm{IA} \\
\mathrm{IB}\end{array}$ & $\begin{array}{l}35 \\
5\end{array}$ & $\begin{array}{l}35 \\
3\end{array}$ & $\begin{array}{l}16 \\
0\end{array}$ & $\begin{array}{l}10 \\
0\end{array}$ & $\begin{array}{l}96 \\
8\end{array}$ & 0.48 \\
\hline Grade & $\begin{array}{l}1 \\
2 \\
3\end{array}$ & $\begin{array}{l}18 \\
14 \\
8\end{array}$ & $\begin{array}{l}22 \\
12 \\
4\end{array}$ & $\begin{array}{l}10 \\
4 \\
2\end{array}$ & $\begin{array}{l}9 \\
1 \\
0\end{array}$ & $\begin{array}{l}59 \\
31 \\
14\end{array}$ & 0.32 \\
\hline
\end{tabular}


38 Residual Disease after Operative Hysteroscopy Simonsen et al.

\section{Discussion}

Several studies have evaluated concomitant EC and endometrial polyps, ${ }^{1,4,13}$ but this group of patients must be better characterized, aiming to tailor surgery and adjuvant treatment. The present study was performed at 2 cancer centers, where besides oncologic treatment, hysteroscopies are also usually performed to diagnose endometrial diseases.

The mean age and menopausal status of our patients were similar to those in previous studies. ${ }^{14-16}$ We recorded a higher rate of asymptomatic patients, compared with previous studies, ${ }^{17,18}$ concluding that hysteroscopic investigation of polyps can identify cases of initial EC, even in patients who still have no symptoms, such as vaginal bleeding. ${ }^{1,19,20}$ Indeed, cancer that is associated with polyps appears to present at earlier stages, compared with those that do not, ${ }^{1}$ but this probably does not cause an impact on survival rates. ${ }^{21}$

The diagnosis of cancer as an unexpected finding occurred in $9.6 \%$ of the patients. They had undergone a pathological examination of polyps, which suggested a benign alteration (atypical hyperplasia), but the definitive pathological report described adenocarcinoma. This finding has been corroborated by other studies. ${ }^{7,8,22}$ This situation was less frequent than that reported in the GOG 167, in which the prevalence of endometrial cancer after hysterectomy with atypical hyperplasia was $42.6 \%{ }^{23}$ Notably, a systematic review confirmed that when the atypical hyperplasia is restricted to polyps, $<10 \%$ of the final specimen would be expected to have cancer. ${ }^{7}$

At least 10 studies have evaluated definitive pathological reports of patients with an endometrial tumor that involved polyps (-Table 4). The criteria for patient selection varied significantly among studies, with some having a hysteroscopic focus ${ }^{1,24,25}$ and others evaluating oncological outcomes and detailing the staging and follow-up. 2,5,6,26-29
In our series, when the polyp was associated with cancer, the tumor in most cases involved the polyp, (78 cases, 75\%), but in $38.5 \%$, it was restricted to the polyp and in $36.5 \%$, there was also endometrial involvement. With our findings, it was not possible to establish whether the malignancy is more likely to affect the polyp tissue or the adjacent endometrium. Conversely, our data suggest that the tumor randomly affects the adjacent polyp or the endometrium. Similarly, Farrell et al. $^{2}$ reported the involvement of the adjacent endometrium in $61.5 \%(16 / 26)$ of cases and 6 cases had no residual disease in the final pathologic uterine specimen (23\%).

Complete removal of the polyp when the tumor was restricted to the polyp was achieved in $18 / 40$ cases (45\%), but only in 9 (50\%) of them it resulted in a uterine specimen without cancer. This finding suggests that hysteroscopy is not very accurate for distinguishing neoplastic tissue and that the complete resection of the polyp does not always match the definitive pathological result. ${ }^{27}$

It is possible that an early neoplasm, opportunistically diagnosed in asymptomatic patients, allows for the tumor to be resected entirely by hysteroscopy. If the disease develops, it is expected that tumors that are initiated in pre-existing polyps will affect the base of the polyp and the endometrium. In this context, it would no longer be possible to distinguish the neoplastic polyp from a polypoid neoplasm. ${ }^{2}$

It is more difficult for extra-polyp disease to be removed by hysteroscopy, but $6(15.7 \%)$ of 38 patients in this group had a definitive uterine specimen without cancer. Removal of all EC tissue by hysteroscopy was reported previously in some exceptional situations. ${ }^{28,30}$

Almost all the series described tumors with stages $>$ IA (-Table 4), with the prevalence ranging between 0 and $30 \%$, and some of them have also described stages II-IIIA., ${ }^{1,6,26}$ Although in the present study and in most of the previous

Table 4 Previous studies with endometrioid uterine neoplasms associated with polyps

\begin{tabular}{|c|c|c|c|c|c|}
\hline & $\mathrm{n}$ & $\begin{array}{l}\mathrm{n}(\%) \text { Restricted } \\
\text { to polyps in } \\
\text { hysteroscopy }\end{array}$ & Grade 1 or 2 & $\begin{array}{l}\text { Stage } \\
\text { IA (n/\%) }\end{array}$ & $\begin{array}{l}\text { Absence of residual } \\
\text { tumor in hysterectomy }\end{array}$ \\
\hline Salm (1972)* & 4 & ND & 4 & ND & $1(25 \%)$ \\
\hline Farrell et al. (2005)* & 26 & ND & $25(96.1 \%)$ & $\begin{array}{l}26(100 \%) \\
\text { (selected just IA) }\end{array}$ & $6(23 \%)$ \\
\hline Fernández-Parra et al. (2006) 2,25,29 & 10 & 10 & ND & $8(80 \%)$ & $3(30 \%)$ \\
\hline Giordano et al. (2007) & 5 & $5(100 \%)$ & $5(100 \%)$ & $3(60 \%)$ & $0(0 \%)$ \\
\hline Vilos et al. $(2007)^{26,28}$ & 10 & $10(100 \%)$ & 10 & $10(100 \%)$ & $2(20 \%)$ \\
\hline Mittal et al. (2008)* & 18 & $11(61 \%)$ & ND & $16(88.9 \%)$ & $1(5.6 \%)$ \\
\hline Perri et al. $(2010)^{* *}$ & 125 & ND & $96(76.8 \%)$ & $96(76.8 \%)$ & $13(10.4 \%)$ \\
\hline Wethington et al. (2011) ${ }^{* *}$ & 13 & $3(23.1 \%)$ & ND & ND & ND \\
\hline Gambadauro et al. (2014)* & 12 & ND & $11(91.6 \%)$ & $8(66.7 \%)$ & $0(0 \%)$ \\
\hline Elyashiv et al. $(2017)^{1,5,6,24,27}$ & 18 & ND & ND & $13(72.2 \%)$ & $4(22.2 \%)$ \\
\hline Present study & 104 & 40 (38.5\%) & 86.5 & $96(92.3 \%)$ & $18(17.3 \%)$ \\
\hline
\end{tabular}

Abbreviation: ND, not described.

* Other histological types were excluded from this table.

${ }^{*}$ Other histological types included in the analysis. 
series there was no lymph node involvement, one previous study documented stages III and IV, ${ }^{1}$ suggesting that lymph node evaluation could not be omitted. We excluded nonendometrioid types from our analysis, due to the particularly aggressive behavior of the disease in this group. ${ }^{2}$

The inherent nature of a retrospective study hindered a more precise hysteroscopic characterization of the biopsy site, especially the location of the tumor in the polyp. Conversely, several years would be necessary to recruit this sample in a prospective study.

Because blind biopsies usually have a lower diagnostic accuracy, ${ }^{31,32}$ a potential bias of our study is that, in certain cases, the biopsy was performed after a diagnostic hysteroscopy with curettage, rather than with a working instrument. Nevertheless, blind avulsion of the polyp using the appropriate materials and standardized technique leads to an adequate pathological analysis. ${ }^{33}$ In the case of curettage, the sample fragmentation makes it impossible to differentiate whether the biopsy came from the polyp or the endometrium. ${ }^{34}$

Another concern is that certain patients with polypoid cancer were inadvertently included, due to poor hysteroscopic descriptions when the exam was performed outside of the referred services. In some hysteroscopies, only the appearance of the polyp, and not that of the adjacent endometrium, was described.

The absence of pathological indicators of the low aggressiveness of tumors that are restricted to polyps is our most important finding. The strength of our study is its large sample size in comparison with other studies on polyps and cancer, and our data confirm that even patients with endometrioid EC that is apparently restricted to the polyp in hysteroscopy, regardless of histological grade, can experience deep myometrial invasion.

\section{Conclusion}

In conclusion, there was no association between polyp location of the EC during hysteroscopy and less residual disease or absence of deep myometrial invasion in the final uterine specimen.

\section{Contributions}

Study concepts: Simonsen M. and Baiocchi Neto G. Study design: Simonsen M. and Baiocchi Neto G. Data acquisition: Simonsen M., Mantoan H., Faloppa C. C., Kumagai L. Y., Badiglian-Filho L., Machado A. G., Tayfour N. M., Baiocchi Neto G. Quality control of data and algorithms: Mantoan H., Faloppa C. C., Kumagai L. Y., Badiglian-Filho L., Machado A. G., Tayfour N. M. Data analysis and interpretation: Simonsen M. and Baiocchi Neto G. Statistical analysis: Simonsen M. and Baiocchi Neto G. Manuscript preparation: Simonsen M. and Baiocchi Neto G. Manuscript editing: Simonsen M. and Baiocchi Neto G. Manuscript review: Simonsen M., Mantoan H., Faloppa C. C., Kumagai L. Y., Badiglian-Filho L., Machado A. G., Tayfour N. M., Baiocchi Neto G.

Conflict of Interests

The authors have no conflict of interests to declare.
Acknowledgments

The authors acknowledge Mrs. Bruna Tirapelli Gonçalves from the Hospital AC Camargo for supporting the research data enabling appropriate statistical analysis.

\section{References}

1 Perri T, Rahimi K, Ramanakumar AV, Wou K, Pilavdzic D, Franco EL, et al. Are endometrial polyps true cancer precursors? Am J Obstet Gynecol. 2010;203(03):232.e1-232.e6. Doi: 10.1016/j.ajog.2010.03.036

2 Farrell R, Scurry J, Otton G, Hacker NF. Clinicopathologic review of malignant polyps in stage $1 \mathrm{~A}$ carcinoma of the endometrium. Gynecol Oncol. 2005;98(02):254-262. Doi: 10.1016/j.ygyno.2005.03.044

3 Dias DS, Bueloni-Dias FN, Dias R, Nahás-Neto J, Nahás EAP, Leite NJ, et al. Usefulness of clinical, ultrasonographic, hysteroscopic, and immunohistochemical parameters in differentiating endometrial polyps from endometrial cancer.J Minim Invasive Gynecol. 2014;21 (02):296-302. Doi: 10.1016/j.jmig.2013.09.015

4 Antunes A Jr, Costa-Paiva L, Arthuso M, Costa JV, Pinto-Neto AM. Endometrial polyps in pre- and postmenopausal women: factors associated with malignancy. Maturitas. 2007;57(04):415-421. Doi: 10.1016/j.maturitas.2007.04.010

5 Mittal K, Da Costa D. Endometrial hyperplasia and carcinoma in endometrial polyps: clinicopathologic and follow-up findings. Int J Gynecol Pathol. 2008;27(01):45-48. Doi: 10.1097/pgp.0b013e3 $18074 f d 60$

6 Gambadauro P, Martínez-Maestre MA, Schneider J, Torrejón R. Malignant and premalignant changes in the endometrium of women with an ultrasound diagnosis of endometrial polyp.J Obstet Gynaecol. 2014;34(07):611-615. Doi: 10.3109/01443615.2014.916255

7 de Rijk SR, Steenbergen ME, Nieboer TE, Coppus SF. Atypical endometrial polyps and concurrent endometrial cancer: a systematic review. Obstet Gynecol. 2016;128(03):519-525. Doi: 10.1097/AOG.0000000000001566

8 Pivano A, Crochet P, Carcopino X, Cravello L, Boubli L, Agostini A. Risk of coexisting endometrial carcinoma in case of atypical endometrial hyperplasia diagnosed on total hysteroscopic resection. Eur J Obstet Gynecol Reprod Biol. 2016;203:210-213. Doi: 10.1016/j.ejogrb.2016.05.049

9 Ouyang C, Frimer M, Hou LY, Wang Y, Goldberg GL, Hou JY. Malignant endometrial polyps in uterine serous carcinoma: the prognostic value of polyp size and lymphovascular invasion. Int J Gynecol Cancer. 2018;28(03):524-528. Doi: 10.1097/IGC.0000000000001213

10 Chang-Halpenny CN, Natarajan S, Hwang-Graziano J. Early stage papillary serous or clear cell carcinoma confined to or involving an endometrial polyp: outcomes with and without adjuvant therapy. Gynecol Oncol. 2013;131(03):598-603. Doi: 10.1016/j. ygyno.2013.10.010

11 Ben-Arie A, Goldchmit C, Laviv Y, Levy R, Caspi B, Huszar M, et al. The malignant potential of endometrial polyps. Eur J Obstet Gynecol Reprod Biol. 2004;115(02):206-210. Doi: 10.1016/j.ejogrb.2004.02.002

12 National Comprehensive Cancer Network. NCCN guidelines for treatment of cancer by site: Uterine neoplasms: NCCN guidelines [Internet]. 2020 [cited 2020 Jan 10]. Available from: https://www. nccn.org/professionals/physician_gls/pdf/uterine.pdf

13 Bakour SH, Khan KS, Gupta JK. The risk of premalignant and malignant pathology in endometrial polyps. Acta Obstet Gynecol Scand. 2000; 79(04):317-320. Doi: 10.1034/j.1600-0412.2000.079004317.x

14 Tarney CM, Tian C, Wang G, Dubil EA, Bateman NW, Chan JK, et al. Impact of age at diagnosis on racial disparities in endometrial cancer patients. Gynecol Oncol. 2018;149(01):12-21. Doi: 10.1016/j.ygyno.2017.07.145

15 Sivridis E, Giatromanolaki A. The pathogenesis of endometrial carcinomas at menopause: facts and figures. J Clin Pathol. 2011; 64(07):553-560. Doi: 10.1136/jcp.2010.085951

16 Gawron I, Łoboda M, Babczyk D, Ludwin I, Basta P, Pityński K, Ludwin A. Endometrial cancer and hyperplasia rate in women before menopause with abnormal uterine bleeding undergoing endometrial sampling. Przegl Lek. 2017;74(04):139-143 
17 Ghoubara A, Emovon E, Sundar S, Ewies A. Thickened endometrium in asymptomatic postmenopausal women - determining an optimum threshold for prediction of atypical hyperplasia and cancer. J Obstet Gynaecol. 2018;38(08):1146-1149. Doi: 10.1080/01443615.2018.1458081

18 Koh WJ, Abu-Rustum NR, Bean S, Bradley K, Campos SM, Cho KR, et al. Uterine Neoplasms, Version 1.2018, NCCN Clinical Practice Guidelines in Oncology. J Natl Compr Canc Netw. 2018;16(02): 170-199. Doi: 10.6004/jnccn.2018.0006

19 Baiocchi G, Manci N, Pazzaglia M, Giannone L, Burnelli L, Giannone E, et al. Malignancy in endometrial polyps: a 12-year experience. Am J Obstet Gynecol. 2009;201(05):462.e1-462.e4. Doi: 10.1016/j.ajog.2009.05.055

20 Cohen I. Endometrial polyps in pre-and postmenopausal women: factors associated with malignancy. Maturitas. 2008;59(01): 99-100. Doi: 10.1016/j.maturitas.2007.08.005

21 Gemer O, Segev Y, Helpman L, Hag-Yahia N, Eitan R, Raban O, et al. Is there a survival advantage in diagnosing endometrial cancer in asymptomatic postmenopausal patients? An Israeli Gynecology Oncology Group study. Am J Obstet Gynecol. 2018;219(02):181. e1-181.e6. Doi: 10.1016/j.ajog.2018.05.013

22 Naaman Y, Diment J, Perlman S, Oustinov N, Vaisbuch E, Ben-Arie A. Can malignant potential of endometrial polyps be determined by incorporating the endometrial intraepithelial neoplasia (EIN) classification? Gynecol Oncol. 2015;136(02):254-257. Doi: 10.1016/j. ygyno.2014.12.014

23 Trimble CL, Kauderer J, Zaino R, Silverberg S, Lim PC, Burke JJB II, et al. Concurrent endometrial carcinoma in women with a biopsy diagnosis of atypical endometrial hyperplasia: a Gynecologic Oncology Group study. Cancer. 2006;106(04):812-819. Doi: 10.1002/cncr.21650

24 Wethington SL, Herzog TJ, Burke WM, Sun X, Lerner JP, Lewin SN, Wright JD. Risk and predictors of malignancy in women with endometrial polyps. Ann Surg Oncol. 2011;18(13):3819-3823. Doi: 10.1245/s10434-011-1815-z

25 Fernández-Parra J, Rodríguez Oliver A, López Criado S, Parrilla Fernández F, Montoya Ventoso F. Hysteroscopic evaluation of endometrial polyps. Int J Gynaecol Obstet. 2006;95(02):144-148. Doi: 10.1016/j.ijgo.2006.07.007
26 Giordano G, Gnetti L, Merisio C, Melpignano M. Postmenopausal status, hypertension and obesity as risk factors for malignant transformation in endometrial polyps. Maturitas. 2007;56(02): 190-197. Doi: 10.1016/j.maturitas.2006.08.002

27 Elyashiv O, Sagiv R, Kerner R, Keidar R, Menczer J, Levy T. Hysterscopic resection of premalignant and malignant endometrial polyps: is it a safe alternative to hysterectomy? J Minim Invasive Gynecol. 2017;24(07):1200-1203. Doi: 10.1016/j. jmig.2017.08.002

28 Vilos GA, Edris F, Al-Mubarak A, Ettler HC, Hollett-Caines J, AbuRafea B. Hysteroscopic surgery does not adversely affect the longterm prognosis of women with endometrial adenocarcinoma. J Minim Invasive Gynecol. 2007;14(02):205-210. Doi: 10.1016/j. jmig.2006.10.010

29 Salm R. The incidence and significance of early carcinomas in endometrial polyps. J Pathol. 1972;108(01):47-53. Doi: 10.1002/ path.1711080106

30 Wang F, Yu A, Xu H, Zhang X, Li L, Lou H, et al. Fertility preserved hysteroscopic approach for the treatment of stage Ia endometrioid carcinoma. Int J Gynecol Cancer. 2017;27(09):1919-1925. Doi: 10.1097/IGC.0000000000001109

31 Spadoto-Dias D, Bueloni-Dias FN, Elias LV, Leite NJ, Modotti WP, Lasmar RB, Dias R. The value of hysteroscopic biopsy in the diagnosis of endometrial polyps. Womens Health (Lond). 2016; 12(04):412-419. Doi: 10.1177/1745505716653695

32 Svirsky R, Smorgick N, Rozowski U, Sagiv R, Feingold M, Halperin $\mathrm{R}$, Pansky M. Can we rely on blind endometrial biopsy for detection of focal intrauterine pathology? Am J Obstet Gynecol. 2008;199(02):115.e1-115.e3. Doi: 10.1016/j.ajog.2008.02.015

33 Kanthi JM, Remadevi C, Sumathy S, Sharma D, Sreedhar S, Jose A. Clinical study of endometrial polyp and role of diagnostic hysteroscopy and blind avulsion of polyp. J Clin Diagn Res. 2016;10(06): QC01-QC04. Doi: 10.7860/JCDR/2016/18173.7983

34 Savelli L, De Iaco P, Santini D, Rosati F, Ghi T, Pignotti E, Bovicelli L. Histopathologic features and risk factors for benignity, hyperplasia, and cancer in endometrial polyps. Am J Obstet Gynecol. 2003; 188(04):927-931. Doi: 10.1067/mob.2003.247 